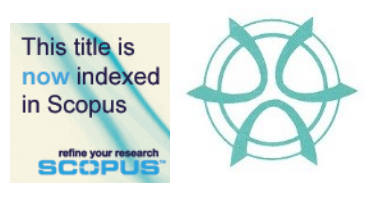

\title{
DETERMINATION OF FINANCIAL FEASIBILITY OF INDONESIA'S NEW CAPITAL ROAD CONSTRUCTION PROJECT USING SCENARIO ANALYSIS
}

\author{
Muhammad Heru Akhmadi ${ }^{1}$, Audra Rizki Himawan ${ }^{2}$ \\ School of Financial Management \\ POLYTECHNIC OF STATE FINANCE STAN, INDONESIA
}

\begin{abstract}
The plan to relocate the Indonesian capital from Jakarta to East Kalimantan Province in 2024 requires a significant amount of 442 trillion Rupiah to construct various new capital infrastructure such as roads for transportation. This study aims to analyze the funding scheme for new capital road construction projects in Indonesia using two alternative financing, namely the National Budget and Public-Private Partnership (PPP). This study used quantitative methods with a scenario analysis approach to determine the best funding scheme based on regional economic growth and financial viability. This study did not consider the project management factors during the construction period and the quality factors of the roads built during the concession period. The results showed that road construction projects in the new capital city can be implemented using two financing schemes. The National Budget financing scheme will increase the percentage of the budget deficit to GDP in the first five years of development. The financing scheme through PPP can help the government overcome the budget deficit but requires the resilience of the government's budget during the project concession period.
\end{abstract}

Keywords: infrastructure, scenario analysis, financing, new capital

\footnotetext{
${ }^{1}$ Lecturer at Polytechnic of State Finance STAN, Email: heru.cio@gmail.com
} 
PLANNING MALAYSIA

Journal of the Malaysia Institute of Planners (2021)

\section{INTRODUCTION}

The government has been planning to relocate the Indonesian national capital from Jakarta to some other state even before it gained independence. Based on data compiled by Kompas Research and Development (2019), Bandung in West Java, Palangkaraya in Central Kalimantan, and Jonggol were being considered during the Dutch East Indies era, and Presidents Soeharto and Soekarno's times in office. Finally, President Jokowi established the Kutai Kertanegara and North Penajam Paser Regencies, East Kalimantan Province, as Indonesia's new capital.

The Ministry of National Development Planning has reported that an estimated cost of IDR 466 trillion is needed to construct new capital. This is expected to lead to an increase in APBN spending in the next few years. Given the limited fiscal space, an alternative financing procedure, namely a partnership scheme between the government and business entities or SOEs' assignment, was adopted for this construction, thereby enabling APBN spending to be allocated to other public sectors.

One factor that determines the readiness to develop the new capital is road construction. Its provision is important because it is regarded as a basic infrastructure that connects various economic aspects, including access both in and out of the capital. Moreover, the planned capital Kutai Kertanegara and Pasir Penajam Districts lack adequate road infrastructure. Although the Ministry of PPN intends to execute its construction using the Public-Private Partnership scheme, besides it is important to review the financing feasibility of capital roads.

The PPP is implemented supposing the road construction has economic and financial feasibility, thereby providing added value to the companies to get their investment returns. Therefore, this study ensures that the government's choice of the PPP scheme is realistic compared to other alternative financing initiatives, such as SOE special assignments and bilateral loans from international institutions.

However, this study aims to determine the feasibility of road construction using an economically sustainable financing scheme that benefits the government and reduces fiscal risks in the long run. This led to the adoption of a funding initiative that meets the 3 aforementioned criteria. Before calculating the financing feasibility, a scenario analysis approach was adopted to determine the road requirements based on the estimated number of existing and migratory populations. Meanwhile, the government has yet to formalize the design and technical drawings related to the construction of these roads.

\section{RESEARCH METHODOLOGY}

This study uses quantitative methods to analyze the determination of financing schemes for developing the new capital city of Indonesia. Furthermore, inference statistics were used to calculate the average and standard deviations of road requirements. Some data that serve as independent variables include population, 
Muhammad Heru Akhmadi \& Audra Rizki Himawan

Determination of Financial Feasibility of Indonesia's New Capital Road Construction Project Using Scenario Analysis

area size, and Gross Regional Domestic Product (GRDP) in the Kutai Kertanegara and Penajam Pasir Utara districts were used to determine the estimated length of the road. The results showed that the estimated length of road and the yield data of Rupiah denominated government securities are used as independent variables to determine the estimated project based on several scenarios.

According to Kishita et al. (2016), the scenario analysis is a method used to predict the possible occurrence of a situation and its consequences, assuming that the phenomenon or a trend is continued in the future. The scenario analysis is carried out through 4 stages. The first is estimating the road construction requirements based on Minimum Service Standards using the following variables, population, and GDRP per area. The second stage is to estimate the average population parameters according to a small sample size to ascertain the road construction project costs. Third, extrapolate Government Bonds (SBN) Yield Curve in Rupiah Denominations as Discount Rate, and trend compilation using scatter-plots and logarithmic natural (ln) to estimate the interest rates for 50 years as an input in the NPV calculation.

The fourth stage involves analyzing the scenarios to determine the changes in independent variables, determined by a set of values. Based on this, the independent variables are projects and a range of estimated values determined by an inferential statistical approach. Conversely, the dependent variable is a primary balance and the ratio of deficits to GDP. Income expenditure is the control variable in accordance with ceteris paribus. However, the addition of the project value results in capital expenditure.

\section{LITERATURE REVIEW}

Sumardjoko (2019) stated that the provision of infrastructure creates connectivity and trade. Based on the managerial status of the authority, there are national, provincial, district, city, and village roads. National roads are described as arterial collectors in the primary road network system that strategically connects provincial capitals, national and toll lanes. Provincial roads are collectors in the primary road network system that strategically connects provincial, and district, or city lanes. City roads are a secondary road network system connecting service centers, parcels, and settlements within the city. Village roads are also categorized as public lanes that connect the area or settlements within the community and environmental roads.

However, technical inefficiency has a greater deviation in the efficient frontier compared to the ineffective scale (Chuweni, 2019). In road construction, technical requirements include the speed of the plan, width, capacity, driveways, intersections of complementary buildings, equipment, usage according to their functions, and the ability to meet the security, safety, and environmental needs. To guarantee all these, Government Regulation No. 25 of 2000 stipulated a 
minimum service standard, which is developed from 3 basic desires of road users. This includes good road conditions, non-congested lanes, and durability. Based on the Decree of Ministry for Public Works and Human Settlements Number 14 of 2010, several aspects of the service sector that need to be met in constructing this infrastructure are accessibility, mobility, and safety measures.

The accessibility aspect is described as the availability of roads connecting the district or city activity centers. Its parameter is the ratio of the total road length to the population density. The higher the accessibility indexes, the better availability of interconnecting roads. The magnitude of the Minimum Service Standards accessibility index parameters is shown in Table 1.

Table 1: Accessibility Index Values

\begin{tabular}{|r|c|c|c|c|}
\hline Category & $\begin{array}{c}\text { Population density } \\
\text { (per } \mathbf{~ k m}^{\mathbf{2}} \text { ) }\end{array}$ & $\begin{array}{c}\text { GRDP per } \\
\text { capita (billion) }\end{array}$ & $\begin{array}{c}\text { Accessibility } \\
\text { Index Values }\end{array}$ & $\begin{array}{c}\text { Mobility } \\
\text { Index Values }\end{array}$ \\
\hline Very high & $>5.000$ & $>10$ & $>5,00$ & $>5,00$ \\
\hline High & $>1.000$ & $>5$ & $>1,50$ & $>2,50$ \\
\hline Moderate & $>500$ & $>2$ & $>0,50$ & $>1,00$ \\
\hline Low & $>100$ & $>1$ & $>0,15$ & $>0,50$ \\
\hline Very Low & $<=100$ & $<=1$ & $>0,05$ & $>0,20$ \\
\hline \multicolumn{4}{r|r|}{ Source: Minister for Public Works and Human Settlements }
\end{tabular}

The mobility aspect is the quality of road services, measured by the ease per individual community to travel to a certain destination. This aspect is calculated using the proportion of available road length and the population with the magnitude of the minimum service standard parameter based on the Gross Regional Domestic Revenue per capita. Furthermore, the safety aspect is the availability of roads that ensures users drive safely, including the addition of equipment such as traffic signs, etc.

The calculated project feasibility is an essential factor that determines the success of road construction, and this starts with the preparation of cash flow projections. According to Titman et al. (2018), this procedure involves 4 steps. First, measure the project's operating cash flow, obtained by calculating operating income, project, tax, and depreciation expenses. The net profit realized after the tax payment is referred to as Net Operating Profit After Taxes (NOPAT). The second is identifying the additional net operating working capital needed. The third is identifying the capital expenditure, while the fourth involves reducing net cash flow per year (free cash flow / FCF). This is realized by adding the net operating working capital and capital expenditure.

In carrying out a feasibility assessment, it is necessary to consider the overall costs incurred and the return on investment period. The annuity method is an alternative approach for calculating these costs. According to Titman et al. (2018), an annuity is a series of payments with similar nominal for a certain number of years. The model is an implication of two financial management principles. First, money with similar nominal has a time value which means that 
Muhammad Heru Akhmadi \& Audra Rizki Himawan

Determination of Financial Feasibility of Indonesia's New Capital Road Construction Project Using Scenario Analysis

its current worth tends to be enormous compared to the future. Second, cash flow is a source of value. In addition, Titman et al. (2018) stated that it is the amount of money obtained from a business operating within the same period. This led to the generation of two models, namely ordinary and maturity annuities. The usual one involves the making of payments at the end of the period (n). The annuity due is the ability to make payments (PMT) at the beginning of the period (n) with an interest rate (i). The present values (PV) of an ordinary annuity and its due are shown in Equations 1.1 and 1.2, respectively.

$$
\begin{gathered}
P V=P M T\left(\frac{1-\frac{1}{(1+i)^{n}}}{i}\right) \\
P V=P M T\left(\frac{1-\frac{1}{(1+i)^{n}}}{i}\right)(1+i)
\end{gathered}
$$

Recognizing the cash flow risks in project implementation and evaluation method, namely the net present value (NPV), is developed to map these issues and returns, which are helpful in the decision-making process. The NPV method guides project innovation by indicating potential financial value (Žižlavský, 2014). Conversely, it is adopted during optimal decision-making (Arya, 1998).

Titman (2018) stated that the discount factor is used to calculate the NPV between expenditure and income. In addition, it is also obtained using the social opportunity cost of the capital. Meanwhile, assuming it is related to the cash flow projection method, the NPV is the amount of net cash flow throughout the project duration that has been discounted to produce the present value. The intended cash flow includes estimated investment, operating, maintenance costs, and benefits from the planned project.

The basic NPV formula is shown in Equation 1.3, where $\mathrm{CF}_{0}$ is the initial cash outlay, usually represented by a negative number, $\mathrm{CF}_{1}$ through $\mathrm{CF}_{\mathrm{n}}$ represents cash flow expectations for periods 1 through $\mathrm{n}$. It is important to note that these cash flow expectations are either positive (inflows) or negative (outflows), $\mathrm{k}$ is the desired rate of return or discount rate used to calculate the present or expected value of future cash flows, and $\mathrm{n}$ is the cash flow period for the project being evaluated.

$$
N P V=C F_{0}+\frac{C F_{1}}{(1+k)^{1}}+\cdots+\frac{C F_{n}}{(1+k)^{n}}
$$

NPV reflects three principles: first, money has a time value. Second, the higher the rate of return, the higher the risks encountered, and third, cash flow is a source of value. In addition, to the NPV analysis, several aspects need attention. First, the estimated cash has to be based on a tax basis. Second, cash outflow need not be included in the element of interest, supposing the project is funded with a loan. These interest costs are the required rate of return for the project appraisal. However, assuming the interest payments are calculated based 
on project cash outflow, double results are obtained. This is because as part of borrowing costs, it is recorded as cash outflows for funding activities.

\section{RESULT AND DISCUSSION}

\section{Calculation of Estimated Road Construction Needs}

The estimated road construction needs must be optimized using asset performance measurement, thereby enabling efficient public planning involving several alternative cost requirements (Puspitarini, 2019). The expectant numbers of residents in Penajam Paser Utara and Kutai Kartanegara Districts by 2024 are $2,559,746$, with a population density of 84 people per square kilometre. The projection referred to considers the geometric average population growth of $0.95 \%$ and $2.48 \%$ in North Penajam Paser and Kutai Kartanegara Districts, respectively, yearly from 2011 to 2018 . However, this population growth was not caused by the migration of government employees and their families to the capital city. Therefore, an estimated increase of $175.62 \%$ has been predicted to occur from 2018 to 2024 .

A weighted average was used according to the population to obtain a single GRDP per capita value for the two districts. The combined per capita GDRP in 2024 is projected to be Rp247.05 million. In the same year, the per capita GRDP of North Penajam Paser and Kutai Kartanegara Districts are projected at Rp74.42 million and Rp279.74 million, respectively. This calculation is based on the assumption that the economy is constantly growing at an average rate of $5 \%$.

According to the Minimum Service Standards, road length is calculated based on the accessibility index. Furthermore, with a population density of 84 people per square kilometre, the minimum accessibility index referred to in the Decree of the Minister of Settlement and Regional Infrastructure Number 534 / KPTS / M / 2001 is 0.05 . Based on the calculation that considered the length of the existing clean road and the total area of the two regencies, which were realized as 2,061.88 km and 30,596 square $\mathrm{km}$, respectively, an accessibility index of 0.07 was obtained. Therefore, it was discovered that the accessibility index realization was higher than the Minimum Service Standards. In conclusion, the net length of the existing roads met the Minimum Service Standards.

Furthermore, the length of the road is calculated based on the mobility index. Considering the projected GDP per capita 2024 in two districts and minimum mobility index of 5 , The net length of existing roads and the value per thousand population are $2,061.88 \mathrm{~km}$ and $2,559,746$, respectively. The mobility index of 0.81 is obtained which still below the Minimum Service Standards. Therefore, to meet the specified standard, the required road length is $12,798.73$ $\mathrm{km}$.

In accordance with the 2 approaches, assuming a one-way lane is 11 meters wide compared to the minimum primary arterial road width stipulated in 
Muhammad Heru Akhmadi \& Audra Rizki Himawan

Determination of Financial Feasibility of Indonesia's New Capital Road Construction Project Using Scenario Analysis

government regulation No. 34 of 2006, as $12,798.73 \mathrm{~km}$, the resulting area of the project is 281.57 square $\mathrm{km}$. or $0.92 \%$. Conclusively, the length of the road is acceptable considering that the percentage of its area is less than $5 \%$.

\section{Development of Project Value Scenarios}

Scenario development needs to shift from the traditional approach, namely the project feasibility study, to a new method that adheres to the sustainable development principles (Shen, 2010). The value of needs per kilometre is calculated using an inferential statistical approach, considering projects executed close to the new capital. The data processing results carried out on 5 samples of road development projects on Kalimantan Island obtained an average value of IDR7.64 billion with a standard sample deviation of IDR 2.47 billion. Furthermore, the average population interval estimation method was used to obtain the $t$ distribution as illustrated in Equation 1.4, with a free degree of 4 and an error value of $5 \%$, including an average interval of project values per $\mathrm{km}$ of IDR4.57 billion and IDR10.71 billion.

$$
\begin{aligned}
& p\left(\bar{X}-t_{(0,025,4)} \frac{s}{\sqrt{n}}<\mu_{x}<\bar{X}+t_{(0,025,4)} \frac{s}{\sqrt{n}}\right)=1-0,05 \\
& p\left(\operatorname{Rp} 7,64 \mathrm{~m}-2,776 \frac{R p 2,47 m}{\sqrt{5}}<\mu_{x}<\operatorname{Rp} 7,64 \mathrm{~m}+2,776 \frac{R p 2,47 m}{\sqrt{5}}\right)=0,95 \\
& p\left(\operatorname{Rp} 4,57 \mathrm{~m}<\mu_{x}<\operatorname{Rp} 10,71 \mathrm{~m}\right)=0,95
\end{aligned}
$$

From this formula, the road construction needs in the new capital are calculated by multiplying the length of the required road $(12,798.73 \mathrm{~km})$ and the estimated range of project values. The results obtained led to the generation of three funding scenarios for the construction projects are shown in table 3 .

Table 3: Value Scenarios of Road Development Projects

\begin{tabular}{|l|c|r|r|}
\hline \multicolumn{1}{|c|}{ Scenario } & $\begin{array}{c}\text { The length of the } \\
\text { road (km) }\end{array}$ & $\begin{array}{c}\text { Unit per km } \\
\text { (IDR billion) }\end{array}$ & \multicolumn{1}{c|}{$\begin{array}{c}\text { Project value } \\
\text { (IDR billion) }\end{array}$} \\
\hline Low & $10.736,85$ & 4,57 & $49.073,41$ \\
\hline Moderate & $10.736,85$ & 7,64 & $82.049,71$ \\
\hline High & $10.736,85$ & 10,71 & $115.026,01$ \\
\hline
\end{tabular}

The next step is preparing cash flow projections in accordance with several assumptions. First, the road construction duration is 5 years with a utilization period of 50 years as stipulated in Government Regulation Number 27 of 2014 concerning Management of State Property. Second, the discount rate used is the yield of government securities denominated in Rupiah with a tenure of 50 years. However, assuming the data is not found, an extrapolation method is applied using the logarithmic function based on natural numbers (ln). Annual maintenance costs are $5 \%$ of the project value. 
Depreciation expense is calculated using the straight-line method with no residual value and useful life of 50 years. The assumption used to calculate the capital expenditure increase is based on the analysis that the project tends to be carried out for 5 years with an annual completion rate of $20 \%$ of the road length target. The final assumption is that it is not a commercial road, therefore, users are not charged any form of tariff or fees.

Financial feasibility models are calculated based on inputs and indicators (Kurniawan, 2015). In accordance with the assumptions and scenarios, the calculated cash flow projections are shown in table 4 for the low, moderate, and high project value scenarios. The results show that all scenarios have a negative cash flow.

Table 4: Project Cash Flow Projects with Scenarios in billion (rupiah)

\begin{tabular}{|c|c|c|c|c|c|c|}
\hline & \multicolumn{2}{|c|}{ Low } & \multicolumn{2}{|c|}{ Moderate } & \multicolumn{2}{|c|}{ High } \\
\hline & $<5$ years & 5-54 years & $<5$ years & $5-54$ years & $<5$ years & 5-54 years \\
\hline Cash inflow & & & & & & \\
\hline Revenue & & 0 & & 0 & & 0 \\
\hline Cash Outflow & & & & & & \\
\hline Maintenance & & $(2.453,67)$ & & $(4.102,49)$ & & $(5.751,30)$ \\
\hline Depreciation & & $(981,47)$ & & $(1.640,99)$ & & $(2.300,52)$ \\
\hline $\begin{array}{l}\text { Net Operating } \\
\text { Profit }\end{array}$ & & $(3.435,14)$ & & $(5.743,48)$ & & $(8.051,82)$ \\
\hline Tax & & - & & - & & - \\
\hline NOPAT & & $(3.435,14)$ & & $(5.743,48)$ & & $(8.051,82)$ \\
\hline (+) Depreciation & & 981,47 & & $1.640,99$ & & $2.300,52$ \\
\hline Operating CF & & $(2.453,67)$ & & $(4.102,49)$ & & $(5.751,30)$ \\
\hline $\begin{array}{l}\text { Increase in } \\
\text { Capex }\end{array}$ & $(9.814,68)$ & & $(16.409,94)$ & & $(23.005,20)$ & \\
\hline FCF & $(9.814,68)$ & $(2.453,67)$ & $(16.409,94)$ & $(4.102,49)$ & $(23.005,20)$ & $(5.751,30)$ \\
\hline
\end{tabular}

The second assumption proves that a discount rate of $8.339 \%$ was realized using the yield curve extrapolation, thereby making it possible for the Net Present Value (NPV) for all project value scenarios to be calculated. The results show that all scenarios have negative NPV with IDR57.96 trillion, IDR96.90 trillion, and IDR135.85 trillion in the low, moderate, and high categories. The results indicate that the road construction project was not financially feasible.

\section{Financing Scheme for Indonesia's New Capital Road Project}

The government adopted 3 schemes in financing the new capital road construction projects. These include APBN capital expenditure, the assignment of State-Owned Enterprises (SOE), and Public-Private Partnerships (PPP). The SOE assignment scheme was implemented because it was in accordance with the specified criteria (Ansari, 2017) and considering the fact that the project's scenarios cash flow has 
Muhammad Heru Akhmadi \& Audra Rizki Himawan

Determination of Financial Feasibility of Indonesia's New Capital Road Construction Project Using Scenario Analysis

negative NPV values. Investment risk is bound to occur, assuming the government continues to assign $\mathrm{SOE}$ because it reduces the company's equity.

The PPP scheme with the availability of payment facilities was also applied. The government and the private sector tend to share the risk associated with this scheme. One of its advantages is that the private sector receives payments from the government during concession yearly. In addition, payment is made once the road construction complies with the output and service performance indicators specified in the agreement. This scheme reduces the contraction of short-term financing in the budget. However, financing schemes through state government spending tend to be implemented considering that roads are free public usage. In accordance with the construction of new capital roads, the financial losses are covered by the citizens' tax receipt. Based on the 3 financing schemes, the availability payment and state government spending serve as alternatives.

According to the theory of the monetary time value, a payment trajectory based on assumption is formulated in the context of implementing the PPP scheme. First, the road concession period, asides from the construction duration, are 50 years. Second, the discount rate used is the estimated interest rate of Rupiah denominated SBN with tenure of 50 years based on the yield curve extrapolation result of $8.339 \%$. In addition, it was also reported that the annual maintenance costs carried out by the Implementing Business Entity is 5\% of the project value and is constant. Therefore, the costs incurred by the government are shown in table 6 .

Table 6: Government Payments in PPP Scheme For 50 Years in Rp billion

\begin{tabular}{|c|c|c|c|}
\hline Scenario & Payment of Project & Maintenance Cost & Total \\
\hline Low & $(4.195,42)$ & $(2.453,67)$ & $(6.649,09)$ \\
\hline Moderate & $(7.014,66)$ & $(4.102,49)$ & $(11.117,15)$ \\
\hline High & $(9.833,90)$ & $(5.751,30)$ & $(15.585,20)$ \\
\hline
\end{tabular}

It is a trade-off when considering alternative road construction financing schemes using government budgets or private company budgets. If the government considers project financing using the government budget (APBN), the need for capital expenditure budget for the first five years of project development will be high. This is a dilemma when there are other budgetary needs such as additional health spending. However, there are advantage using this scenario where the allocation of road maintenance spending during the concession period is not significant.

The alternative financing schemes using PPP have advantages because of the project risks that are shared by the government and the private sector $(\mathrm{Ke}$, 2010). Private companies will finance the road construction project for 5 years with their budget. Furthermore, after the construction project is completed, the government will pay the development costs incurred and the profits. This payment period is called the concession period. Sometimes during the concession period, the 
government gives permission to private companies to collect revenue from those who use the road as part of the company's profits.

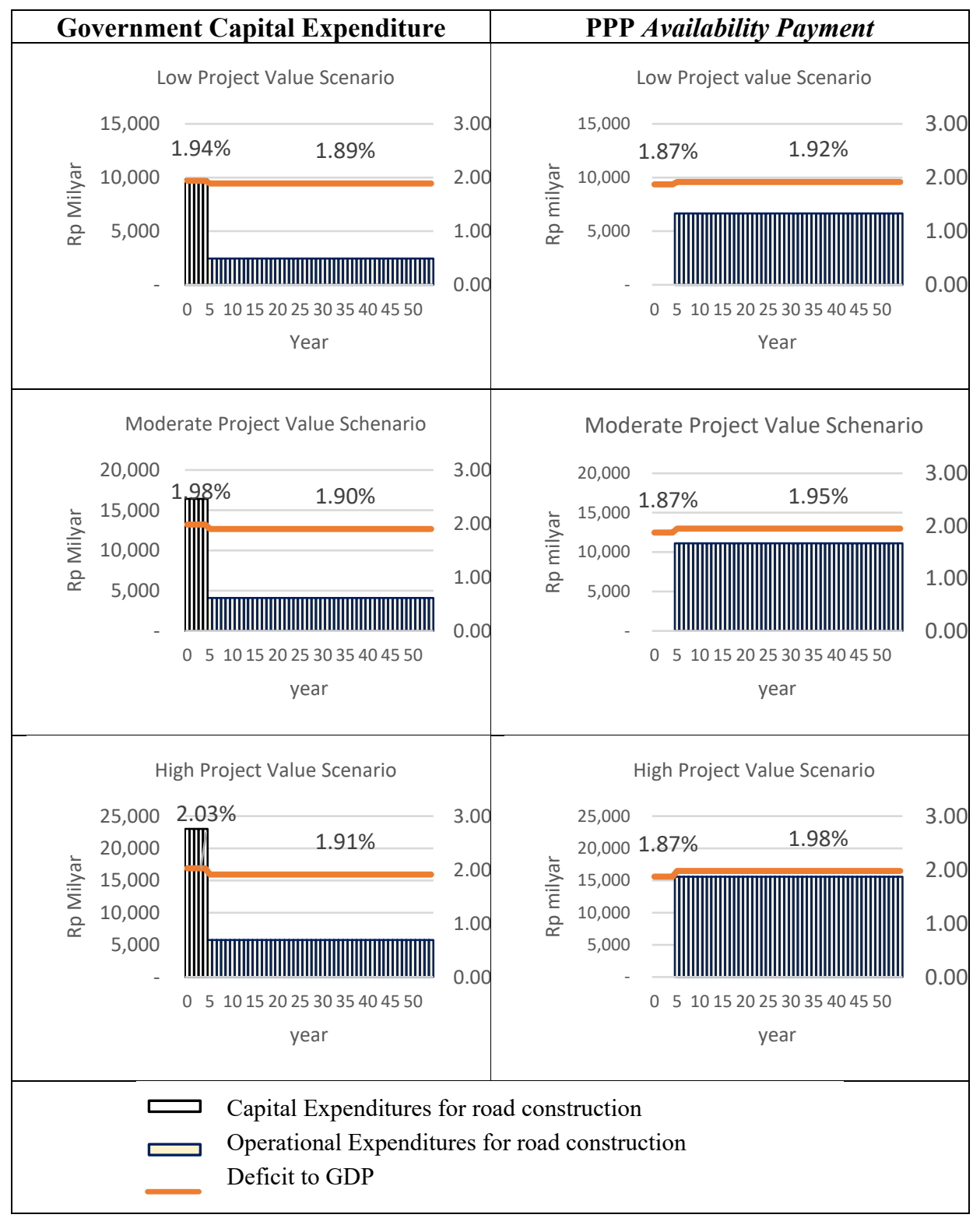

Figure 1: Simulation Results of the Impact of Using a Financing Scheme against the State Budget Deficit in the Long Term 
Muhammad Heru Akhmadi \& Audra Rizki Himawan

Determination of Financial Feasibility of Indonesia's New Capital Road Construction Project Using Scenario Analysis

\section{CONCLUSION}

Road construction as a form of connectivity from one place to another is one of the challenges facing the development of new capital. The use of scenario analysis shows that the needs of the project are not financially feasible therefore, the government has to adopt the APBN capital expenditure funding scheme and PPP availability payment. However, the use of these methods encouraged the government to provide a working budget for the next 50 years. The APBN capital expenditure financing method is preferred to the PPP scheme, because it has less impact on the budget allocated to finance road construction projects during the first 5 years. Furthermore, the use of the PPP scheme is associated with numerous risks. However, within 6 to 50 years, the government needs to provide a budget allocation to pay for the return on investment of the business entity. The second financing schemes are risky, the government needs to consider the best that does not have an negative impact on the government budget. Finally, the results of this study do not consider the project management factors during the construction period and the quality factors of the roads built during the concession period. We assume the project management and road quality using these two scenarios are the same.

\section{REFERENCES}

Ansari, M. I. (2017). Government Assignment in the State Owned Enterprise in the Electricity Sector in the Corporate Law Perspective. Padjadjaran Journal of Law, 4(3), 551-568.

Arya, A., Fellingham, J. C., \& Glover, J. C. (1998). Capital budgeting: Some exceptions to the net present value rule. Issues in Accounting Education, 13, 499-508.

Aulia, Mohamad Donie. 2011. Analysis of Road Requirements in the New City Area of Tegalluar District of Bandung. Majalah Ilmiah UNIKOM, Vol. 11, No. 1. Bandung: UNIKOM.

Central Bureau of Statistics. 2015. Kutai Kartanegara Regency in Figures. Kutai Kartanegara: Badan Pusat Statistik.

Chuweni, N. N. (2019). Measuring technical efficiency of Malaysian real estate investment trusts: a data envelopment analysis approach. PLANNING MALAYSIA, 17(9).

Ke, Y., Wang, S., \& Chan, A. P. (2010). Risk allocation in public-private partnership infrastructure projects: comparative study. Journal of infrastructure systems, 16(4), 343-351.

Kishita, Y., Hara, K., Uwasu, M., \& Umeda, Y. (2016). Research needs and challenges faced in supporting scenario design in sustainability science: a literature review. Sustainability Science, 11(2), 331-347.

Kurniawan, F., Mudjanarko, S. W., \& Ogunlana, S. (2015). Best practice for financial models of PPP projects. Procedia Engineering, 125, 124-132.

Puspitarini, I., \& Akhmadi, M. H. (2019). Measuring Public Asset Performance Using Outputbased Approach: Evidence from Indonesia. PLANNING MALAYSIA, 17(9). 
PLANNING MALAYSIA

Journal of the Malaysia Institute of Planners (2021)

Shen, L. Y., Tam, V. W., Tam, L., \& Ji, Y. B. (2010). Project feasibility study: the key to successful implementation of sustainable and socially responsible construction management practice. Journal of cleaner production, 18(3), 254-259.

Sumardjoko, I., \& Akhmadi, M. H. (2019). Development of Connectivity Infrastructure as Economic Leveraging Power and Poverty Reduction in East Java. Jurnal Manajemen Keuangan Publik, 3(1), 22-31.

Titman, Sheridan. Arthur J. Keown. John D. Martin. (2018). Financial Management: Principles and Applications, Thirteenth Edition. Harlow: Pearson.

Qomarsono, Hilman. (2016, Edisi 1). Government Guarantee for Financing the Trans Sumatra Toll Project by PT Hutama Karya (Persero). Info Risiko Fiskal. Jakarta: Direktorat Pengelolaan Risiko Keuangan Negara, DJPPR.

Žižlavský, O. (2014). Net present value approach: method for economic assessment of innovation projects. Procedia-Social and Behavioral Sciences, 156(26), 506-512.

Received: $12^{\text {th }}$ July 2021. Accepted: $23^{\text {rd }}$ Sept 2021 